\title{
ANALISIS FAKTOR-FAKTOR YANG MEMPENGARUHI KADAR HB IBU HAMIL DI WILAYAH KERJA PUSKESMAS ANDALAS KOTA PADANG
}

\author{
ANAL YSIS OF FACTORS AFFECTING PREGNANT WOMEN'S HB \\ LEVEL IN THE WORKING AREA OF PUSKESMAS ANDALAS \\ PADANG CITY
}

\author{
Ade Nurhasanah Amir ${ }^{1 *}$, Marisa Lia Anggraini ${ }^{2}$, Fanny Jessica ${ }^{3}$ \\ STIKes Syedza Saintika Padang \\ Adheknurhasanaha@gmail.com,085274832282
}

\begin{abstract}
ABSTRAK
Kadar hemoglobin merupakan indikator biokimia untuk mengetahui status gizi ibu hamil. World Health Organization (WHO) merekomendasikan kadar hemoglobin ibu hamil ideal adalah $\geq 11$ $\mathrm{gr} / \mathrm{dl}$ dan tidak dibawah 10,5 gr/dl pada trimester II kehamilan. Tinggi rendahnya kadar hemoglobin selama kehamilan mempunyai pengaruh terhadap berat bayi lahir karena dapat mengakibatkan gangguan pertumbuhan janin di dalam kandungan. Salah satu penyebab terjadinya pendarahan diakibatkan oleh rendahnya kadar hemoglobin pada ibu hamil. Penelitian ini untukmengetahui faktor-faktor yang berhubungan dengan kadar hemoglobin pada ibu hamil. Penelitian ini menggunakan jenis penelitian survey analitik dengan pendekatan cross sectional. Teknik menggunakan total sampling dengan jumlah 200 ibu hamil. Hasil penelitian menunjukkan $(46,0 \%)$ 92 ibu hamil dengan kadar hemoglobin anemia dan (54,0\%) 108 ibu hamil dengan anemia. Penelitian ini menunjukkan bahwa kadar hemoglobin dipengaruhi oleh variabel usia kehamilan $(\mathrm{p}=0.018)$. Mayoritas responden yang mengalami anemia adalah pada trimester ke 2 . Pada masa kehamilan trimester 2 ibu mengalami proses hemodilusi. Sebagai seorang ibu hamil pada trimester 2 memiliki risiko untuk mendapatkan anemia.
\end{abstract}

Kata Kunci: Hemoglobin, Kehamilan

\begin{abstract}
ABSTRAK
Hemoglobin level is biochemical indicator to determine the nutrition status of pregnant women. World Health Organization (WHO) recommends that ideal level of hemoglobin for pregnant women is $\geq 11 \mathrm{~g} / \mathrm{dl}$ and not below 10,5 g/dl on the second trimester of pregnancy. Increasing and decreasing of hemoglobin levels during pregnancy influences birth weight because it can cause intrauterine growth disruption One of the bleeding causes is low hemoglobin levels on pregnant mothers. This research aims to find out the factors correlated with hemoglobin levels on pregnant mothers. This research used the survey analytic research type with cross sectional approach. The technique applied used with 200 pregnant mothers as the population. The research results show that 92 pregnant mothers (46\%) with anemia and 108 pregnant mothers (54\%) with no anemia. This research shows that the hemoglobin levels are influenced by the age of pregnancy (pvalue=0.018). Majority of respondents who have anemia were at 2 nd trimester. At thoos trimester mothers have hemodilusi process. As a resolt, pregnant mothers at 2nd primer havemort rish to get anemia.
\end{abstract}

Keywords: Hemoglobin,Pregnancy 


\section{Jurnal Kesehatan Saintika Meditory}

\section{PENDAHULUAN}

Pembangunan dibidang kesehatan tidak bisa dilepaskan dari upaya mewujudkan kesehatan anak sedini mungkin sejak dalam kandungan. Upaya ke- sehatan ibu telah dipersiapkan sebelum dan selama kehamilan bertujuan untuk mendapatkan bayi yang sehat. Gangguan kesehatan yang terjadi selama ke- hamilan dapat mempengaruhi kesehatan janin dalam kandungan hingga kelahiran dan pertumbuhan bayi selanjutnya. ${ }^{(3,6)}$

Kekurangan kadar hemoglobin $(\mathrm{Hb})$ ibu hamil merupakan salah satu permasalahan kesehatan yang rentan terjadi selama kehamilan. Kadar $\mathrm{Hb}$ yang kurang dari 11 $\mathrm{g} / \mathrm{dl}$ mengindikasikan ibu hamil menderita anemia. Anemia pada ibu hamil meningkatkan resiko mendapatkan Bayi Berat Lahir Rendah (BBLR), risiko perdarahan sebelum dan saat persalin- an, bahkan dapat menyebabkan kematian ibu dan bayinya jika ibu hamil tersebut menderita anemia berat. Hal ini tentunya dapat memberikan sumbangan

besarterhadapangkakematianibubersalinma upunangka kematian bayi, dimana berdasarkan SDKI tahun 2007 angka tersebut masih cukup tinggi, yaitu angka kematian ibu (AKI) 228 per 100.000 kelahiran hidup dan angka kematian bayi (AKB) 34 per 1.000 kelahiran hidup.

Salah satu penyebab terjadinya pendarahan diakibatkan oleh rendahnya kadar hemoglobin pada ibu hamil. Hemoglobin merupakan komponen sel darah merah yang berfungsi menyalurkan oksigen ke seluruh tubuh. Berkurangnya hemoglobin menyebabkan anemia. Pada ibu hamil biasanya mengalami hemodelusi. Di Indonesia prevalensi anemia kehamilan relatif tinggi, yaitu $38 \%-71,5 \%$ dengan rerata $63,5 \%$ (Baharudin, Dkk, 2014). Kadar hemoglobin yang dibawah normal, akan mengganggu aktifitas dalam tubuh. Kadar hemoglobin di atas $11 \mathrm{gr} \%$ pada trimester I dan III atau kadar $>10,5 \mathrm{gr} \%$ pada trimester II merupakan nilai batas normal kadar hemoglobin. Nilai batas tersebut dan perbedaannya dengan kondisi wanita tidak hamil terjadi karena hemodilusi, terutama pada trimester II (Saifuddin, 2010). Fungsi hemoglobin bertindak sebagai unit pembawa oksigen darah yang membawa oksigen dari paru- paru ke sel-sel, serta membawa CO2 kembali ke paru-paru (Arisman, 2010). Upaya perbaikan gizi pada ibu hamil adalah pemberian Fe. Pemberian Fe pada ibu hamil diharapkan dapat menaikan kadar hemoglobin pada ibu hamil agar tidak terjadi anemia.

Anemia didefinisikan sebagai suatu keadaan kadar hemoglobin ( $\mathrm{Hb})$ di dalamdarah lebih rendah daripada nilai normal untuk kelompok orang menurut umurdan jenis kelamin (Wirjatmadi \& Adriana, 2012). Pada kehamilan kebutuhan oksigen lebih tinggi sehingga memicu peningkatan produksi eritropoietin. Akibatnya, volume plasma bertambah dan sel darah merah (eritrosit) meningkat. Namun, peningkatan volume plasma terjadi dalam proporsi yang lebih besar jika dibandingkan dengan peningkatan eritrosit sehingga terjadi penurunan konsentrasi hemoglobin $(\mathrm{Hb})$ akibat haemodelusi (Kinanthi, 2016).

Dari hasil yang telah dilakukan menurut Oktaviani, dkk (2016) faktor-faktor yang dapat mempengaruhi kadar hemoglobin pada ibu hamil adalah usia ibu $(p=0,000)$ karena pada usia yang masih muda, perkembangan organ-organ reproduksi dan fungsi fisiologinya belum optimal. Selain itu emosi dan kejiwaannya belum cukup matang, sehingga pada saat kehamilan ibu tersebut belum dapat menanggapi kehamilannya secara 


\section{Jurnal Kesehatan Saintika Meditory}

Volume 4 Nomor 1 | https://jurnal.syedzasaintika.ac.id

sempurna dan sering terjadi komplikasi. Ibu hamil yang termasuk umur reproduksi tidak sehat lebih banyak yang menderita anemia dibanding ibu hamil yang termasuk umur reproduksi sehat. Ibu hamil dalam kelompok umur reproduksi tidak sehat yaitu ibu hamil yang berumur $>35$ tahun. Umur kehamilan $(p=0,042)$ yaitu ibu hamil trimester 1 akan memiliki resiko lebih rendah dibanding trimester 2, dan trimester 2 memiliki resiko 4,3 kali dibanding trimester 3 . Paritas $(\mathrm{p}=0,000)$ yaitu seorang wanita yang sudah melahirkan lebih dari 2 kali, dan jika terjadi kehamilan lagi maka kesehatannya akan mulai menurun, sering mengalami kurang darah (anemia). Jarak kehamilan $(p=0,000)$ yang terlalu dekat dapat menyebabkan terjadinya anemia, karena kondisi ibu masih belum pulih dan pemenuhan kebutuhan zat-zat gizi belum optimal, sudah harus memenuhi kebutuhan nutrisi janin yang dikandungnya.

Penurunan kadar hemoglobin dari normal disebut anemia pada ibu hamil adalah kondisi ibu dengan kadar hemoglobin $(\mathrm{Hb})$ dalam darah $<11,0 \mathrm{gr} \%$ pada trimester 1 dan 3, dan $<10,5 \mathrm{gr} \%$ pada trimester 2 atau keadaan jumlah eritrosit lebih rendah dari normal sebagai akibat kekurangan satu atau lebih zat pembentukan darah, salah satunya zat besi. Akibat adanya anemia pada ibu, maka dapat terjadi gangguan pada janin dalam bentuk abortus, terjadi kematian intrauterine, persalinan prematuritas tinggi, berat badan lahir rendah (BBLR), kelahiran dengan anemia, dapat terjadi cacat bawaan, bayi mudah terserang infeksi sampaikematian perinatal,intelegensia rendah (cacat otak), kematian neonatal dan asfiksia intrapartum (Manuaba, 2010).

Menurut Astuti (2016) pendidikan $(\mathrm{p}=0,008)$ Tingkat pendidikan ibu hamil dapat menyebabkan keterbatasan dalam upaya menangani masalah gizi dan kesehatannya. Pengetahuan gizi dan kesehatan akan berpengaruh terhadap pola konsumsi pangan. Status gizi $(p=0,000)$ pada seorang ibu hamil jika kekurangan gizi tentu saja akan menyebabkan akibat yang buruk bagi ibu dan janin. Kekurangan gizi dapat menyebabkan ibu menderita anemia, suplai darah yang mengantarkan oksigen dan makanan pada janin akan terhambat, sehingga janin akan mengalami gangguan pertumbuhan dan perkembangan. Oleh karena itu pemantauan gizi ibu hamil sangatlah penting dilakukan.

Sebagai tenaga kesehatan, bidan mempunyai peranan yang strategis, menurut Keputusan Menteri Kesehatan Republik Indonesia Nomor 369/MENKES/SK/III/2007, standar kompetensi bidan ke3 yaitu bidan memberikan asuhan antenatal yang bermutu tinggi untuk mengoptimalkan kesehatan selama kehamilan yang meliputi: deteksi dini, pengobatan, atau rujukan untuk komplikasi tertentu. Dalam melakukan asuhan antenatal, bidan memberikan ANC terpadu dimana salah satu komponen pelayanan kesehatan ibu hamil yaitu pemberian zat besi sebanyak 90 tablet Fe (Depkes,2015).

Peran masyarakat dalam menanggapi angka kejadian anemia sudah cukup tinggi, tetapi masih terdapat masyarakat khususnya ibu hamil yang tidak patuh terhadap peraturan pemerintah. Ketidak patuhan dalam penerapan program Pemerintah dapat menyebabkan meningkatnya resiko masalah kesehatan. Laporan menunjukan bahwa 20\% dari jumlah pasien yang opname di rumah sakit karena anemia merupakan akibat dari tidak patuhnya pasien terhadap aturan pengobatan dan pemeriksaan kadar hemoglobin. Penelitian ini bertujuan untuk mengetahui faktor-faktor yang 
berhubungan dengan kadar hemoglobin pada ibu hamil di Puskesmas Andalas Kota Padang.

\section{BAHAN DAN METODE}

Penelitian dilakukan di Wilayah Kerja Puskesmas Andalas Kota Padang pada bulan Oktober 2020 sampai September 2020. Metode pengambilan sampelnya adalah dengan cara consecutive sampling.
Instrument penelitian yang digunakan adalah kuesioner untuk pengisian identitas responden, peralatan untuk pengukuran kadar hemoglobin dengan metode cyanmethemoglobin. Data yang diperoleh diolah dengan software computer yaitu SPSS, dan untuk analisis hasil penelitiannya digunakan uji korelasi Pearson dengan tingkat pemaknaan $p<0,05$.

\section{HASIL DAN PEMBAHASAN}

Tabel 1 Distribusi Frekuensi Setiap Variabel Penelitian

\begin{tabular}{|c|c|c|c|c|}
\hline No & Responden & f & Jumlah & $\%$ \\
\hline \multirow[t]{3}{*}{1} & Kadar Hb Ibu hamil & & & \\
\hline & Anemia & 92 & & 46,0 \\
\hline & Tidak Anemia & 108 & & 54,0 \\
\hline \multirow[t]{3}{*}{2} & Umur ibu hamil & & & \\
\hline & Beresiko & 41 & & 20,5 \\
\hline & Tidak Beresiko & 159 & & 79,5 \\
\hline \multirow[t]{4}{*}{3} & Usia Kehamilan & & & \\
\hline & TM3 & 20 & & 10 \\
\hline & TM2 & 80 & & 40 \\
\hline & TM1 & 100 & & 50 \\
\hline \multirow[t]{3}{*}{4} & Paritas & & & \\
\hline & Beresiko & 191 & & 95,5 \\
\hline & Tidak Beresiko & 9 & & 4,5 \\
\hline \multirow[t]{3}{*}{5} & Status Gizi & & & \\
\hline & Beresiko & 43 & & 21,5 \\
\hline & Tidak Beresiko & 157 & & 78,5 \\
\hline
\end{tabular}

Berdasarkan tabel 1 hasil uji menunjukkan bahwa dari 200 responden didapatkan hasil status kadar hemoglobin dengan tidak anemia berjumlah $108 \quad(54,0 \%)$. Variabel umur ibu hamil terbanyak pada umur tidak bersiko yaitu 159 responden $(79,5 \%)$. Variabel usia kehamilan terbanyak pada TM 1 yaitu 100 responden $(50 \%)$. Varibael paritas terbanyak pada paritas beresiko yaitu 191 responden $(95,5 \%)$ dan valiabel status gizi terbanyak pada status gizi ibu hamil tidak beresiko yaitu 157 responden $(78,5 \%)$ 
Hubungan Antara Umur Ibu Hamil Dengan Kadar Hemoglobin Ibu Hamil Berdasarkan tabel 4.2 dari 92 responden yang anemia didapatkan kejadian anemia pada umur tidak beresiko yaitu 71 responden (77,2\%) sedangkan dari 108 responden yang tidak anemia didapatkan 88 responden $(81,5 \%)$ yang dengan umur tidak beresiko. Hasil uji statistic didapatkan dengan Chi-square diketahui nilai $\mathrm{p}>\alpha$ (0.05) sehingga dapat dinyatakan bahwa tidak ada hubungan antara umur ibu hamil degan kadar hemoglobin ibu hamil di Puskesmas Andalas Kota Padang. Sedangkan koefesien kontingensi $\mathrm{C}=0,05$, yang berarti keeratan hubungan ini sangat lemah.Peneliti dapat menyimpulkan bahwa anemia terjadi pada umur ibu tidak beresiko antara 20-35 tahun, hal ini tidak ada perbedaan yang bermakna antara umur ibu yang berumur $<20$ tahun dan $>35$ tahun dengan ibu yang berumur antara 20-30 tahun. Hal ini menunjukkan bahwa hasil analisis hubungan antara usia dan kadar hemoglobin mendapatkan sebanyak 41 responden $(80,4 \%)$ dari kelompok usia tidak berisiko (20-35 tahun) memiliki kadar hemoglobin $11 \mathrm{~g} / \mathrm{dl}$ sebanyak 3 responden(5,9\%).

Hasil uji statistic yang didapatkan nilai $\mathrm{P}=0,476$, sehingga dapat disimpulkan bahwa hal ini menunjukan bahwa tidak adanya hubungan faktor yang berpengaruh usia ibu dengan kadar hemoglobin pada ibu hamil.

\section{Hubungan Antara Usia Kehamilan Dengan Kadar Hemoglobin Ibu Hamil}

Berdasarkandari 92 responden yang anemia sebagian besar didapatkan dengan kejadian anemia pada trimester Ilyaitu 45 responden (48,9\%). Sedangkan dari 108 responden yang tidak anemia sebagian besar didapatkan $64(59,3 \%)$ responden usia kehamilan pada trimester I. Hasil uji statistic didapatkan dengan Chi-square diketahui nilai $\mathrm{p}<\alpha(0.05)$ sehingga dapat dinyatakan bahwa ada hubungan antara usia kehamilan degan kadar hemoglobin ibu hamil di Puskesmas Andalas Kota Padang. Sedangkan koefesien kontingensi $\mathrm{C}=0,197$, keeratan hubungan ini sangat lemah.Penelitian ini dapat diartikan kejadia anemia pada trimester II terjadi karena adanya hemodilusi darah yang biasa menyebabkan anemia. Hal ini menunjukan bahwa hasil uji statistic diperoleh nilai $p$ value $=0.000$ maka dapat disimpulkan ada hubungn yang bermakna antara jarak kehamilan dengan status anemia pada ibu hamil. Tarwoto (2013) juga berpendapat bahwa pada ibu hamil yang memasuki usia kehamilan trimester 2 akan mengalami hemodulusi yang menyebabkan terjadinya pengenceran darah, pertambahan darah tidak sebanding dengan pertambahan plasma, kurangnya zat besi dalam makanan dan kebutuhan zat besi meningkat. Pertambahan tersebut berbanding sebagai berikut yaitu, plasma $30 \%$, sel darah $18 \%$, dan hemoglobin 19\%.

Kadar Hemoglobin bila tidak teratasi akan mempengaruhi kadar Hemoglobin pada trimester berikutnya. Sehingga semakin tua usia kehamilan resiko ibu hamil menjadi anemia semakin besar. Hal ini sesuai dengan Fikawati (2015), bahwa Kebutuhan zat besi terbesar terjadi pada trimester akhir kehamilan 
dimana janin menyimpan zat besi sebagai cadangan dalam tubuhnya. Ketidak cukupan zat besi akan menyebabkan kekurangan $\mathrm{Hb}$ dalam darah yang diperlukan untuk membawa oksigen kepada janin dan sel ibuhamil.

\section{Hubungan Antara Jarak Kehamilan} Dengan Kadar Hemoglobin Ibu Hamil

Berdasarkan tabel 4 dari 92 responden yang anemia sebagian besar didapatkan kejadian anemia pada jarak kehamilan tidak beresiko yaitu 50 responden (54,3\%) dan dari 108 responden yang tidak anemia terbanyak didapatkan yaitu 62 responden $(57,4 \%)$ pada jarak kehamilan tidak beresiko. Hasil uji statistic didapatkan dengan Chi-square diketahui nilai $\mathrm{p}>\alpha(0.05)$ sehingga dapat dinyatakan bahwa tidak ada hubungan antara jarak kehamilan degan kadar hemoglobin ibu hamil di Puskesmas Andalas Kota Padang. Sedangkan koefesien kontingensi $\mathrm{C}=$ 0,031, keeratan hubungan ini sangat lemah. Hasil penelitian ini dapat diartikan bahwa tidak ada perbedaan antara jarak kehamilan beresiko dengan jarak kehamilan beresiko untuk kadar Hemoglobin ibu hamil.

Hal ini menunjukkan bahwa tidak adanya hubungan antara jarak kehamilan dengan kejadian anemia. Disebabkan karena lebih banyak responden yang memiliki jarak kehamilan lebih dari 2 tahun atau jarak kehamilan tidak beresiko, sedangkan seorang ibu membutuhkan waktu lebih dari 2 tahun untuk memulihkan organ reproduksinya.

\section{Hubungan Antara Paritas Dengan Kadar Hemoglobin Ibu Hamil}

Berdasarkan tabel 5 dari 92 responden yang anemia sebagian besar didapatkan kejadian anemia pada paritas beresiko yaitu 86 responden $(93,5 \%)$ dan dari108 responden yang tidak anemia didapatkan 105 responden $(97,2 \%)$ yang berstatus paritas beresiko. Hasil uji statistic didapatkan dengan Chi-square diketahui nilai $p>\alpha \quad(0.05)$ sehingga dapat dinyatakan bahwa tidak ada hubungan antara paritas degan kadar hemoglobin ibu hamil di Puskesmas Andalas Kota Padang. Sedangkan koefesien kontingensi $\mathrm{C}=0,031$, keeratan hubungan ini sangat lemah. Hal ini dapat diartikan bahwa penelitian ini tidak ada perbedaan antara paritas beresiko dengan tidak beresiko untuk mempengaruhi kadar Hemoglobin ibu hamil.

Hal ini bahwa anemia dipengaruhi oleh kehamilan dan persalinan yang sering, semakin sering seorang wanita mengalami kehamilan dan persalinan akan semakin banyak kehilangan zat besi dan semakin anemis. Hasil penelitian ini bahwa resiko ibu yang mengalami anemia dalam kehamilan salah satu penyebabnya adalah ibu yang sering melahirkan dan pada kehamilan berikutnya ibu kurang memperhatikan asupan nutrisi yang baik dalam kehamilannya (Manuaba(2010).

\section{Hubungan Antara Status Gizi Ibu Hamil Dengan Kadar Hemoglobin Ibu Hamil \\ Berdasarkan tabel 4.6 dari 92 responden yang anemia didapatkan kejadian anemia}


pada status gizi sebagian besar tidak beresiko yaitu 75 responden $(81,5 \%)$ sedangkan dari 108 responden yang tidak anemia didapatkan 82 responden $(75,9 \%)$ yang bersastus gizi tidak beresiko. Hasil uji statistic didapatkan dengan Chi-square diketahui nilai $\mathrm{p}>\alpha$ (0.05) sehingga dapat dinyatakan bahwa tidak ada hubungan antara status gizi ibu hamil degan kadar hemoglobin ibu hamil di Puskesmas Andalas Kota Padang. Sedangkan koefesien kontingensi $\mathrm{C}=$ 0,068, keeratan hubungan ini sangat lemah. Hasil penelitian ini tidak ada perbedaan antara status gizi tidak beresiko dengan anemia dan tidak anemik.

Hal ini sesuai dengan Jurnal e-Biomedik oleh Wiraprasido (2017), bahwahasil uji statistic untuk variabel LILA menunjukkan bahwa kadar hemoglobin $<11$ gr/dL lebih banyak pada responden dengan ukuran LILA $\geq 23,5$ cm (76,5\%) dibandingkan dengan ukuran LILA $<23,5 \mathrm{~cm}(17,6 \%)$. Didapatkan juga nilai $\mathrm{P}=0,409$, yang berarti tidak terdapat hubungan yang sigfikan antara ukuran LILA dan kadarhemoglobin.

Hal ini sejalan dengan teori Irianto (2014) bahwa banyak faktor yang dapat menyebabkan timbulnya anemia, antara lain kurangnya asupan zat besi da protein dari makanan, adanya gangguan absorsi diusus, dan perdarahan akut maupun kronis, dan meningkatnya kebutuhan zat besi seperti pada wanita hamil.

Menurut Manuaba (2010), bahwa bahaya kurangnya status gizi menyebabkan komplikasi baik dalam kehamilan, persalinan dan nifas. Bahaya selamanifas yaitu terjadi subinvolusi uteri menimbulkan perdarahan post partum, memudahkan infeksi puerperium, pengeluaran ASI berkurang, terjadi dekompensasi cordis mendadak setelah persalinan, anemia kala nifas, mudah terjadi infeksi mammae.

\section{KESIMPULAN}

Berdasarkan uraian hasil dan pembahasan diatas dapat di simpulkan bahwa faktor yang mempengaruhi kadar hemoglobin yang paling dominan adalah usia kehamilan sehingga dapat dinyatakan bahwa ada hubungan antara usia kehamilan degan kadar hemoglobin ibu hamil di Puskesmas Andalas Kota Padang

\section{Saran}

Berdasarkan hasil penelitian dan pembahasan ibu hamil dapat melakukan persiapan sejak awal kehamilan agar dapat mengantisipasi adanya komplikasi serta dapat mengidentifikasi faktor anemia yang dapat membahayakan kehamilan.

\section{DAFTAR PUSTAKA}

Arisman. (2010). Gizi Dalam Daur Kehidupan. Jakarta: EGC

Astuti, Dwi. (2016). Faktor Yang Berhubungan dengan Kejadian Anemia pada Ibu Hamil di Puskesmas Undaan Lor Kabupaten Kudus.Jurnal e-clinic (eCI), Vol4, 2016https://ejurnal.poltekkestjk.ac. $\mathrm{id} /$ index.php/JKM/article/view/16 2.

Baharudin, S. Dkk. (2014). Gambaran Kadar Hemoglobin Pada Ibu Hamil Di Puskesmas Bahu Kecamatan 


\section{Jurnal Kesehatan Saintika Meditory}

Volume 4 Nomor 1 | https://jurnal.syedzasaintika.ac.id

Malalayang Kota Manado. Volume 4

Nomor

01.https://ejournal.unsrat.ac.id/index. php/ebiomedik/article/view/11248

Depkes RI. (2013). Pedoman Pemberian Tablet Besi Dan Sirup Besi Bagi Petugas.Jakarta : Dirjen Pembinaan Kesehatan Masyarakat, Direktorat Bina Gizi Masyarakat.

Fikawati, S. Dkk. (2015). Gizi Ibu dan Bayi. Jakarta : Rajagrafindo Persada Hakim, Nuw. (2017). Faktor Faktor Yang Mempengaruhi Kejadian Anemia Padalbu

Hamil Di Puskesmas Ngampilan Yogyakarta dalam http://digilib.unisayogya.ac.id/281 3/1/NASKAH\%20PUBLIKASI.pd $\mathrm{f}$

Irianto, Koes. (2014). Gizi Seimbang dalam Kesehatan Reproduksi.

Bandung:Alfabeta.

Kinanthi.S.L. (2016). Gambaran Kejadian Anemia Pada Ibu Hamil Di Puskesmas Pakualaman Kota Yogyakarta. Skripsi. STIkes Jenderal Achmad Yani Yogyakarta.

Cunningham FG dkk. Adaptasi ibu terhadap kehamilan \& Gangguan pertumbuhan janin. Dalam : Hartanto $\mathrm{H}$ dkk (editor). Obstetri Williams vol 1. Edisi 21. Jakarta : EGC; 2006. hlm. 180- 218;825-50. 